\title{
Evaluation of the Relationship Between Initial Lymphocyte Count and Molecular Response to Imatinib Therapy in Chronic Myeloid Leukaemia Patients
}

\section{Kronik Miyeloid Lösemi Hastalarında Tanı Anı Lenfosit Sayısı ve İmatinib Moleküler Yanıtının Değerlendirilmesi}

\author{
(D) İstemi Serin¹, (D) Mehmet Hilmi Doğu¹, (D) Vahit Can Çavdar², (D) Elif Suyani3
}

1University of Health Sciences Turkey, İstanbul Training and Research Hospital, Clinic of Hematology, İstanbul, Turkey

2University of Health Sciences Turkey, İstanbul Training and Research Hospital, Clinic of Internal Medicine, İstanbul, Turkey

3University of Health Sciences Turkey, Adana City Training and Research Hospital, Clinic of Hematology, Adana, Turkey

\begin{abstract}
Introduction: Chronic myeloid leukaemia (CML) is a myeloproliferative neoplasm characterised by the overproduction of haematopoietic cells in the granulocytic series, involving translocation of chromosomes 9 and 22. The first tyrosine kinase inhibitor, imatinib, used in the treatment of CML, represents one of the most successful targeted therapies marking a new era in the treatment of CML. Many scoring systems such as the Hasford and Sokal systems have been developed to stratify CML patients into risk categories, and to predict patient outcome. We aimed to evaluate the relationship between blood lymphocyte count (BLC) at diagnosis and molecular response to imatinib therapy as a prognostic factor.
\end{abstract}

Methods: A total of 108 chronic phase CML patients diagnosed between January 2010 and January 2020 were evaluated. Patient characteristics, laboratory results, BLC and response to treatment were recorded.

Results: The median BLC was $4,665 / \mathrm{mm}^{3}$ and patients were divided into two groups according to the median BLC as $\leq 4,665 / \mathrm{mm}^{3}$ and $>4,665 / \mathrm{mm}^{3}$. The responses at $3,6,12$ month and the final status of patients, namely achievement of major molecular response or not, did not differ between the two groups of patients.

Conclusion: The introduction of new therapeutic options in CML necessitates improvement in existing risk scoring systems. No direct relationship was found between the initial BLC and imatinib response in CML. However this is the first study exploring the role of $\mathrm{BLC}$ at diagnosis in CML patients receiving imatinib, and further studies that look into lymphocyte subgroups as well as bone marrow lymphocyte count at diagnosis might allow a more precise evaluation about the contribution of lymphocyte count to risk assessment in CML patients.

Keywords: Imatinib, lymphocyte, molecular response, optimal, warning, failure

\section{öz}

Amaç: Kronik miyeloid lösemi (KML), 9 ve 22. kromozomların translokasyonu ve granülositik serideki olgun hücrelerin așırı üretimi ile karakterize miyeloproliferatif bir neoplazmdır. Illk tirozin kinaz inhibitörü olan imatinib, KML tedavisinde yeni bir döneme işaret eden, en başarılı hedefe yönelik tedavilerden birini temsil eder. KML prognoz ve tedavi yanıtının belirlenmesi amacıyla Hasford veya Sokal gibi birçok skorlama sistemi ve risk faktörü geliştirilmiștir. Tanıda mutlak lenfosit sayısı (MLS) ile imatinib moleküler yanıt arasındaki ilișkiyi prognostik bir faktör olarak değerlendirmeyi amaçladık.

Yöntemler: Ocak 2010 ile Ocak 2020 arasında tanı konulan 108 kronik faz KML hastası incelendi. Hasta özellikleri, laboratuvar sonuçları, MLS ve tedaviye yanıt kaydedildi.

Bulgular: Medyan MLS 4.665/ $\mathrm{mm}^{3}$ idi ve hastalar medyan MLS'ye göre $\leq 4.665 / \mathrm{mm}^{3}$ ve $>4.665 / \mathrm{mm}^{3}$ olmak üzere iki gruba ayrıldı. Üç, 6, 12. ay yanıtları ve majör moleküler yanıtı olan veya olmayan hastaların son durumları iki grup arasında farklılık göstermedi.

Sonuç: KML'ye yeni terapötik seçeneklerin dahil edilmesi, risk skorlama sistemlerinin iyileștirilmesini gerektirmektedir. Bașlangıçtaki MLS ile KML'deki imatinib yanıtı arasında doğrudan bir ilişki bulunmamıştır. Ancak bu, imatinib alan KML hastalarında MLS'nin tanıdaki rolünü araștıran ilk çalıșmadır. Ayrıca tanıdaki lenfosit alt gruplarının ve kemik iliği lenfosit sayısının araştırılması, KML hastalarında lenfosit sayısının risk değerlendirmesine katkısı hakkında daha kesin bir değerlendirmeyi mümkün kılabilir.

Anahtar Kelimeler: İmatinib, lenfosit, moleküler yanıt, optimal, uyarı, yetmezlik
Address for Correspondence/Yazışma Adresi: İstemi Serin MD, University of Health Sciences Turkey, İstanbul Training and Research Hospital, Clinic of Hematology, İstanbul, Turkey

Phone: +90 5323172393 E-mail: serinistemi@hotmail.com ORCID ID: orcid.org/0000-0003-1855-774X

Cite this article as/Atıf: Serin I, Doğu MH, Çavdar VC, Suyani E. Evaluation of the Relationship Between Initial Lymphocyte Count and Molecular Response to Imatinib Therapy in Chronic Myeloid Leukaemia Patients. Istanbul Med J 2020; 21(6): 473-476.

(C) Copyright 2020 by the University of Health Sciences Turkey, Istanbul Training and Research Hospital/Istanbul Medical Journal published by Galenos Publishing House

(C) Telif Hakkı 2020 Sağlık Bilimleri Üniversitesi istanbul Ĕgitim ve Araştırma Hastanesi/Istanbul Tıp Dergisi, Galenos Yayınevi tarafından basılmıștır.
Received/Geliș Tarihi: 10.07 .2020 Accepted/Kabul Tarihi: 20.10 .2020 


\section{Introduction}

Chronic myeloid leukaemia (CML), which is characterised by the overproduction of haematopoietic cells, is included in the group of chronic myeloproliferative neoplasms. Although the disease has three distinct clinical phases, namely, chronic phase, accelerated phase and blast phase, most CML patients are diagnosed in the chronic phase $(1,2)$. CML is one of the first conditions linked to a specific chromosomal anomaly caused by a reciprocal translocation between chromosomes 9 and 22. The abnormal chromosome, designated as the Philadelphia (Ph) chromosome forms when a part of chromosome 9 and a part of chromosome 22 break and switch positions. The altered chromosome 22 is referred to as the $\mathrm{Ph}$ chromosome. The breakpoint cluster region (BCR)Abelson ( $A B L$ ) gene which forms on chromosome 22 (Ph chromosome), is the product of fusion of the $A B L$ oncogene from chromosome $9 q 34$ with the BCR on chromosome $22 q 11.2$, i.e. $t(9 ; 22)(q 34 ; q 11.2)$, leading to the generation of a $210 \mathrm{kDa}$ (p210) molecular weight protein. This oncoprotein exhibits increased tyrosine kinase activity which is responsible for the development of the leukemic phenotype in $\mathrm{CML}$ $(2,3)$.

Tyrosine kinases play a vital role in diverse biological processes like cell growth, differentiation and apoptosis through mediating the signalling cascades (4). Imatinib, the first tyrosine kinase inhibitor (TKI) used in the treatment of $\mathrm{CML}$, represents one of the most successful targeted therapies marking a new era in CML treatment (5). Despite the high rates of haematological, cytogenetic and molecular response obtained with imatinib, some CML patients using imatinib, require a switch to another TKI either due to an insufficient response or loss of response to treatment, or drug side effects. Evaluation of response in CML patients receiving TKI is based on the International scale (IS) which is expressed and reported as BCR-ABL $1 \%$ on a log scale standard approach and this evaluation is recommended to be performed at 3, 6, 12 months following treatment initiation, and every 3-6 months thereafter. (6)

Many scoring systems and risk factors have been employed to select the most appropriate therapeutic option to obtain a speedy and effective response for various diseases. Accordingly, we aimed to evaluate the association between the blood lymphocyte count (BLC) at diagnosis and molecular response to imatinib therapy.

\section{Methods}

In this study, 108 chronic phase CML patients, who were diagnosed and followed up at University of Health Sciences Turkey, İstanbul Training and Research Hospital Clinic of Hematology between January 2010 and January 2020, were analysed retrospectively. Patient characteristics including age, gender, white blood cell (WBC) count; BLC, blood neutrophil count, haemoglobin ( $\mathrm{Hb}$ ) level; platelet (PLT) count, presence of splenomegaly and/or hepatomegaly, and response to treatment were recorded from the files of the patients. The response was evaluated according to the European Leukaemia Net (ELN) 2020 recommendations (6). The BCR-ABL levels in peripheral blood were obtained using polymerase chain reaction based on the IS. The responses were grouped as optimal, warning, or failure at 3 months, 6 months and 12 months after the start of imatinib. In addition, instances of switching from imatinib to dasatinib or nilotinib were also noted. According to their

final response status, patients were ultimately divided into two groups: patients with major molecular response and patients with no response. The study protocol was approved by the University of Health Sciences Turkey, İstanbul Training and Research Hospital Ethics Committee (decision no: 988, date: 14.04.2017). Informed consent was obtained from all of our patients to participate in this study.

\section{Statistical Analysis}

SPSS 24 programme was used for statistical evaluation. Data was described as numbers and percentage or median and range, when appropriate. $\chi 2$ Fisher's Exact test was used for evaluating categorical values and Mann-Whitney $\mathrm{U}$ test for continuous values in patient groups. All p-values were 2 -sided with statistical significance at 0.05 alpha levels.

\section{Results}

The clinical data of $108 \mathrm{CML}$ patients at diagnosis is summarised in Table 1. The median age of the patients was 45 (range: 17-80); with 49 (45.3\%) female and 59 (54.7\%) male. The median $\mathrm{Hb}$ value was 11.9 (range: 6.516.6), PLT count was $374,500 \times 10^{3} / \mu \mathrm{L}$ (range: $89,000-1,820,000$ ), WBC was $54,925 / \mathrm{mm}^{3}$ (range: 3,950-286,300), neutrophil count was 41,875/ $\mathrm{mm}^{3}$ (range: 1,430-264,400), BLC was 4,665/ $\mathrm{mm}^{3}$ (range: 1,229-14,550). Fifty-four (50\%) of the patients had splenomegaly and 33 (30.6\%) had hepatomegaly (Table 1).

The median follow-up period was 60.2 (range: 6.1-150.2) months. At 3 months, 81 (75\%) patients had optimal response, 10 (9.3\%) patients had warning response and 17 (15.7\%) patients had treatment failure.

\section{Table 1. Patient characteristics}

\begin{tabular}{|c|c|}
\hline Characteristics & $n=108$ \\
\hline \multicolumn{2}{|l|}{ Gender, n (\%) } \\
\hline Female & $49(45.4 \%)$ \\
\hline Male & $59(54.6 \%)$ \\
\hline Age, years, median (range) & $45(17-80)$ \\
\hline WBC $\left(/ \mathrm{mm}^{3}\right)$, median (range) & $54,925(3,950-286,300)$ \\
\hline Neutrophil (/mm³), median (range) & $41,875(1,430-264,400)$ \\
\hline Lymphocyte (/mm³), median (range) & $4,665(1229-14,550)$ \\
\hline $\mathrm{Hb}$ (g/dL), median (range) & $11.9(6.5-16.6)$ \\
\hline Plt $\left(\times 10^{3} / \mathrm{mm}^{3}\right)$, median (range) & $374,500(89,000-1,820,000)$ \\
\hline \multicolumn{2}{|l|}{ Hepatomegaly, n (\%) } \\
\hline Yes & $33(30.6 \%)$ \\
\hline No & $75(69.4 \%)$ \\
\hline \multicolumn{2}{|l|}{ Splenomegaly, n (\%) } \\
\hline Yes & $54(50 \%)$ \\
\hline No & $54(50 \%)$ \\
\hline Follow-up duration, months, median (range) & $60.2(6.1-150.2)$ \\
\hline Switch of imatinib, n (\%) & $37(34.3 \%)$ \\
\hline TKI switching to dasatinib, n (\%) & $17(15.7 \%)$ \\
\hline TKI switching to nilotinib, $\mathrm{n}(\%)$ & $20(18.5 \%)$ \\
\hline Last response status: MMR, n (\%) & $97(89.8 \%)$ \\
\hline No response, $\mathrm{n}(\%)$ & $10(9.3 \%)$ \\
\hline
\end{tabular}


At 6 months 82 (75.9\%) patients had optimal response, 8 (7.4\%) patients had warning response and 18 (16.6\%) patients had treatment failure. At 12 months 80 (74\%) patients had optimal response, 1 (0.9\%) patient had warning response and 26 (25.9\%) patients had treatment failure. As final response, major molecular response (MMR) was detected in 97 (89.8\%) patients and 10 (9.3\%) patients had no response (Table 2).

Imatinib was switched to a second line TKI in 37 (34.3\%) patients. Twenty (18.5\%) patients were switched to nilotinib because of grade 3 skin toxicity in three patients, grade 4 myalgia in one patient and response failure in 16 patients. Seventeen patients were switched to dasatinib due to grade 4 skin toxicity in five patients, grade 3-4 nausea and vomiting in one patient and response failure in 11 patients (Table 1).

The median BLC was 4,665/mm $\mathrm{mm}^{3}$ (range: 1,229-14,550) and the patients were divided into two groups according to the median BLC as $\leq 4,665$ / $\mathrm{mm}^{3}$ and $>4,665 / \mathrm{mm}^{3}$. Both groups included 54 (50\%) patients each. The responses at 3 months, 6 months, 12 months did not differ between the groups with lymphocyte count $\leq 4,665 / \mathrm{mm}^{3}$ and $>4,665 / \mathrm{mm}^{3}(\mathrm{p}>0.05)$ (Table 3). Regarding the final status of the patients, whether a MMR was achieved or not, the results in the two groups were comparable $(p>0.05)$ (Table 3).

\section{Discussion}

Risk stratification and personalised treatment have increasingly become the mainstay in the management of various diseases. Although

Table 2. Response of patients to imatinib therapy

\begin{tabular}{|l|l|}
\hline $\mathbf{3}$ months optimal, $\mathrm{n}(\%)$ & $\mathbf{n = 1 0 8}$ \\
\hline 3 months warning, $\mathrm{n}(\%)$ & $10(9.3 \%)$ \\
\hline 3 months failure, $\mathrm{n}(\%)$ & $17(15.7 \%)$ \\
\hline 6 months optimal, $\mathrm{n}(\%)$ & $82(75.9 \%)$ \\
\hline 6 months warning, $\mathrm{n}(\%)$ & $8(7.4 \%)$ \\
\hline 6 months failure, $\mathrm{n}(\%)$ & $18(16.6 \%)$ \\
\hline 12 months optimal, $\mathrm{n}(\%)$ & $80(74 \%)$ \\
\hline 12 months warning, $\mathrm{n}(\%)$ & $1(0.9 \%)$ \\
\hline 12 months failure, $\mathrm{n}(\%)$ & $26(25.9 \%)$ \\
\hline
\end{tabular}

the approval of TKIs targeting BCR-ABL has provided a personalised therapeutic option for CML, especially in the chronic phase, risk identification is still essential for a minority of CML patients who show insufficient response to treatment. Three classical risk scoring systems have been described to predict the course of CML: the Sokal score, the Hasford score and European Treatment and Outcome Study (EUTOS) metrics (7-9). While the Hasford and the Sokal risk scoring systems were developed prior to the use of TKIs, EUTOS risk scoring system was evolved based on the use of imatinib, but not the $2^{\text {nd }}$ generation TKIs. With the introduction of new therapeutic options in CML, the risk scoring systems had to be improved. Actually, the ELN recommended using the new EUTOS Long Term Survival score which is calculated based on patient age, spleen size, peripheral blood blast and PLT count. The major issues in this scoring system include problems in the standardisation of spleen size and the fact that it consists of only four parameters. However, a more objective risk assignment becomes important in terms of preference of either a first generation TKI imatinib or a second generation TKI as first line therapy, especially in countries such as Turkey where imatinib is generally chosen as first line TKI therapy for CML patients. From this viewpoint, we evaluated $\mathrm{BLC}$ at diagnosis in patients receiving imatinib and did not find any relationship between the BLC and molecular response to imatinib.

The association between the lymphocyte count and imatinib response was first evaluated by Mustjoki et al. (10) in $37 \mathrm{CML}$ patients. The lymphocyte count in the bone marrow at 3 months and 6 months of imatinib treatment increased significantly in patients responding to therapy. Also early bone marrow lymphocytosis during imatinib therapy was found to be a predictor of optimal response in these patients. However such an outcome could not be verified with BLC since it was observed that there was little or no correlation between bone marrow lymphocyte counts and BLC. This inconsistency between the BLC and bone marrow lymphocyte count could thus explain the results (no relationship of $\mathrm{BLC}$ to molecular response in $\mathrm{CML}$ ) in our study. As another point in contrast, we investigated the BLC at diagnosis, but the effects of lymphocytosis occurring post-TKI treatment seems more prominent in the earlier study.

In our study, we did not investigate the status of lymphocyte subgroups, which might have been more informative in elucidating the role of $\mathrm{BLC}$

Table 3. Comparison of response to the imatinib therapy in patients with blood lymphocyte count $\leq 4,665 / \mathrm{mm}^{3} \mathrm{and}>4,665 / \mathrm{mm}^{3}$

\begin{tabular}{|c|c|c|c|}
\hline & $\begin{array}{l}\leq 4,665 / \mathrm{mm}^{3} \\
\mathrm{n}=54\end{array}$ & $\begin{array}{l}>4,665 / \mathrm{mm}^{3} \\
\mathrm{n}=54\end{array}$ & p \\
\hline 3 months optimal, n (\%) & $41(38 \%)$ & $40(37 \%)$ & \multirow{3}{*}{0.079} \\
\hline 3 months warning, $\mathrm{n}(\%)$ & $2(1.9 \%)$ & $8(7.4 \%)$ & \\
\hline 3 months failure, $\mathrm{n}(\%)$ & $10(9.3 \%)$ & $9(90 \%)$ & \\
\hline 6 months optimal, n (\%) & $41(38 \%)$ & 41 (37.9\%) & \multirow{3}{*}{0.236} \\
\hline 6 months warning, $\mathrm{n}(\%)$ & $2(1.9 \%)$ & $6(5.5 \%)$ & \\
\hline 6 months failure, $n$ (\%) & $11(10.2 \%)$ & $7(6.5 \%)$ & \\
\hline 12 months optimal, $\mathrm{n}(\%)$ & $40(37.4 \%)$ & $40(37.4 \%)$ & \multirow{3}{*}{0.564} \\
\hline 12 months warning, $\mathrm{n}(\%)$ & $1(0.9 \%)$ & $0(0 \%)$ & \\
\hline 12 months failure, $n$ (\%) & $12(11.2 \%)$ & $14(13.1 \%)$ & \\
\hline
\end{tabular}


in prognosis of CML. In CML patients, especially those receiving dasatinib, proliferation of $\mathrm{CD} 8+$, natural killer (NK) and NK/T-like cells has been well established and associated with long lasting treatment response (11-13). In addition, before the TKI era, Kreutzman et al. (13) showed that CML patients treated with interferon (IFN)-alpha had increased numbers of NK-cells and clonal $\gamma \delta(+)$ T-cells when they had a long lasting response. de Castro et al. (14) showed that there was an increase in the percentage of CD8/FasL+, DR/CD3+, DQ/CD3+, CD34/Fas+, DR/CD56+, CD56/FasL+ cells and of IFN-gamma- and IL-2-producing lymphocytes and an increase in NK cytotoxicity in CML patients receiving IFN-alpha, who achieved complete haematological remission.

\section{Conclusion}

No direct relationship was found between the initial BLC and molecular response to imatinib therapy in CML patients. However this is the first study exploring the role of $\mathrm{BLC}$ at diagnosis in CML patients receiving imatinib. The limitations of this study include the retrospective nature of the study and the relatively low number of patients. Additionally, investigation of lymphocyte subgroups and bone marrow lymphocyte count at diagnosis (not undertaken in this study) could allow a more precise evaluation about the contribution of lymphocyte count in the risk assessment in CML patients treated with imatinib.

\section{Ethics}

Ethics Committee Approval: The study protocol was approved by the University of Health Sciences Turkey, İstanbul Training and Research Hospital Ethics Committee (decision no: 988, date: 14.04.2017).

Informed Consent: Informed consent was obtained from all of our patients to participate in this study.

Peer-review: Externally peer-reviewed.

Authorship Contributions: Surgical and Medical Practices- I.S., V.C.Ç.; Concept - M.H.D., I.S.; Design - M.H.D., I.S.; Data Collection or Processing - I.S., V.C.C..; Analysis or Interpretation - I.S.; Literature Searchi.S.; Writing - I.S., M.H.D., E.S.

Conflict of Interest: No conflict of interest was declared by the authors.

Financial Disclosure: The authors declared that this study received no financial support.

\section{References}

1. Kurzrock R, Kantarjian HM, Druker BJ, Talpaz M. Philadelphia chromosomepositive leukemias: from basic mechanisms to molecular therapeutics. Ann Intern Med 2003; 138: 819-30.
2. Sokal JE, Cox EB, Baccarani M, Tura S, Gomez GA, Robertson JE, et al. Prognostic discrimination in "good- risk" chronic granulocytic leukemia. Blood 1984; 63 : 789-99.

3. Hasford J, Pfirrmann M, Hehlmann R, Allan NC, Baccarani M, Kluin-Nelemans $J C$, et al. A new prognostic score for survival of patients with chronic myeloid leukemia treated with interferon alfa. Writing Committee for the Collaborative CML Prognostic Factors Project Group. J Natl Cancer Inst 1998; 90: 850-8.

4. Thapa B, Fazal S, Parsi M, Rogers HJ. Cancer, Myeloproliferative Neoplasms. [Updated 2019 Nov 13]. In: StatPearls Treasure Island (FL): StatPearls Publishing; 2020. Available from: URL: https://www.ncbi.nlm.nih.gov/books/ NBK531464/

5. Deininger MW, Druker BJ. Specific targeted therapy of chronic myelogenous leukemia with imatinib. Pharmacol Rev 2003; 55: 401-23.

6. Hochhaus A, Baccarani M, Silver RT, Schiffer C, Apperley JF, Cervantes F, et al European Leukemia Net 2020 recommendations for treating chronic myeloid leukemia. Leukemia 2020; 34: 966-84.

7. Hu B, Savani BN. Impact of risk score calculations in choosing front-line tyrosine kinase inhibitors for patients with newly diagnosed chronic myeloid leukemia in the chronic phase. Eur J Haematol 2014; 93: 179-86.

8. Hasford J, Baccarani M, Hoffmann V, Guilhot J, Saussele S, Rosti G, et al. Predicting complete cytogenetic response and subsequent progression-free survival in 2060 patients with CML on imatinib treatment: the EUTOS score. Blood 2011; 118: 686-92

9. Aijaz J, Junaid N, Asif Naveed M, Maab R. Risk Stratification of Chronic Myeloid Leukemia According to Different Prognostic Scores. Cureus 2020; 12: e7342. doi: 10.7759/cureus.7342.

10. Mustjoki S, Lundán T, Knuutila S, Porkka K. Appearance of bone marrow lymphocytosis predicts an optimal response to imatinib therapy in patients with chronic myeloid leukemia. Leukemia 2007; 21: 2363-8.

11. Qiu ZY, Xu W, Li JY. Large granular lymphocytosis during dasatinib therapy. Cancer Biol Ther 2014; 15: 247-55.

12. Rohon P, Porkka K, Mustjoki S. Immunoprofiling of patients with chronic myeloid leukemia at diagnosis and during tyrosine kinase inhibitor therapy. Eur J Haematol 2010; 85: 387-98.

13. Kreutzman A, Rohon P, Faber E, Indrak K, Juvonen V, Kairisto V, et al. Chronic myeloid leukemia patients in prolonged remission following interferon- $\alpha$ monotherapy have distinct cytokine and oligoclonal lymphocyte profile. PLoS One 2011; 6: e23022.

14. de Castro FA, Palma PV, Morais FR, Simões BP, Carvalho PV, Ismael SJ, et al. Immunological effects of interferon-alpha on chronic myelogenous leukemia. Leuk Lymphoma 2003; 44: 2061-7. 